\title{
Cristo, o cristianismo e a dessacralização da sociedade atual: Jo 1,14
}

\author{
Orientador: Prof. Waldecir Gonzaga \\ Pesquisador: Fabio Fonseca Costal \\ Fonte: $\mathrm{CNPq}$
}

\section{Introdução}

A segunda fase desta pesquisa tem por objetivo apresentar, a partir de Jo 1,14, a perspectiva, segundo o teólogo Karl Rahner, de como cooperou para o processo reflexivo sobre a questão do advento da Encarnação, a qual se encontra profundamente associada às concepções de sua teologia transcendental. De modo particular, apresentaremos a concepção do homem e o Mistério-Misterioso diante da perspectiva da manifestação do Verbo Encarnado. E ainda, acrescentaremos a compreensão do homem, o qual é convidado à "escuta" da Palavra de Deus, onde o "Shemá Israel" (Dt 6,4-9) corresponde o preceito essencial da fé em Javé.

\section{Objetivos}

Investigar a dessacralização da sociedade atual a partir do Prólogo do Evangelho de João, especialmente em 1,14, evidenciando a centralidade do Mistério de Cristo, a Encarnação, de sobremaneira o entendimento a partir das concepções teológicas de Karl Ranher diante da manifestação do Verbo Encarnado. 